\title{
Before 1962: The Case for 1950s China-India History
}

\section{Citation}

Ghosh, Arunabh. 2017. Before 1962: The Case for 1950s China-India History. The Journal of Asian Studies 76, no. 3: 697-727.

\section{Permanent link}

http://nrs.harvard.edu/urn-3:HUL.InstRepos:41288160

\section{Terms of Use}

This article was downloaded from Harvard University's DASH repository, and is made available under the terms and conditions applicable to Open Access Policy Articles, as set forth at http:// nrs.harvard.edu/urn-3:HUL.InstRepos:dash.current.terms-of-use\#OAP

\section{Share Your Story}

The Harvard community has made this article openly available.

Please share how this access benefits you. Submit a story. 


\section{Before 1962: The Case for 1950s China-India History}

\section{Arunabh Ghosh}

\section{ABSTRACT}

China-India history of the 1950s remains mired in concerns related to border demarcations and a teleological focus on the causes, course, and consequence of the war of 1962. The result is an overt emphasis on diplomatic and international history of a rather narrow form. In critiquing this narrowness, this paper offers an alternate chronology accompanied by two substantive case studies. Taken together, they demonstrate that an approach that takes seriously cultural, scientific and economic life leads to different sources and different historical arguments from an approach focused on political (and especially high political) life. Such a shift in emphasis, away from conflict, and onto moments of contact, comparison, cooperation, and competition, can contribute fresh perspectives not just on the histories of China and India, but also on histories of the Global South.

Arunabh Ghosh (aghosh@fas.harvard.edu) is Assistant Professor of Modern Chinese History in the Department of History at Harvard University

Vikram Seth first learned about the death of "Lita” in the Chinese city of Turfan on a sultry July day in 1981. Today’s celebrated poet and novelist was then an unknown Stanford University graduate student, about to embark upon an epic journey hitchhiking his way through Xinjiang, Tibet, and Nepal (Seth 1987). "I hear that Lita died earlier this year,” an officer in the city's General Police Station had told Seth, empathetically adding: "I am very sorry to read about it. We take a lot of interest in Lita and Laz" (Seth 1987: 14). Rita and Raj; the names of the leading protagonists in Bollywood's earliest cross-over hit, Awara (1951; Eng: Vagabond; Ch: Liulangzhe 流浪者). Nargis (1929-1981), the Indian actress who played the role of Rita, had died a couple of months earlier in May and the officer had read about it in a Chinese magazine. ${ }^{1}$ This was not Seth's sole encounter with Awara, nor with its eponymous theme song, which he had heard "hummed on the streets of Nanjing." On multiple occasions, he had to "dust off the perennial favorite” and belt it out in front of appreciative audiences, some of whom invariably joined in (Seth 1987: 11, 40, 128). ${ }^{2}$ 
Seth has the likely distinction of being among the earliest Indians to possess an Awara story. Many Indians who have lived in or traveled through the People's Republic have their own version. These experiences have been notable enough in their frequency to warrant press coverage over the years as well as the occasional academic discussion (Sarkar 2010: 50-53; Aiyar 2010: 45-47; Avasthi 2014; Bhattacharjya 2014; Ghosh 2004; Roy Chowdhury 2008; India Today Online 2011). In each of these discussions, the wonder and bemusement of the experience were juxtaposed with fuzziness about what could have made it possible. Was the film's popularity an artefact of post-Cultural Revolution relaxation, when foreign films began to be screened again? Or could its popularity be traced further back to the 1950s? Perhaps it was Soviet influence that played a decisive role? ${ }^{3}$ Theories were proposed and the odd bit of anecdotal evidence cited, but the fact that the film was first shown as part of an Indian film-week in late 1955, during which two million tickets were sold across twenty major Chinese cities, remained largely forgotten. ${ }^{4}$ It was only with the publication of Krista Van Fleit Hang’s (2014) article that a serious study of the film's reception in China was attempted. And as Van Fleit Hang notes, the film was itself part of a larger exchange that included a similar Chinese film festival held in India earlier that year and bilateral visits by Indian and Chinese delegations of filmmakers (Van Fliet Hang 2014: 143-144; TOI 1955a).

Exceptions such as Van Fleit Hang’s article aside, vagueness about mid-twentieth century China-India history remains the norm. While everyone agrees that the 1950s were the hey-day of Sino-Indian bonhomie, the statement rarely transcends the platitudes and generalities it is encased in. The reason is not hard to find. Late in 1962, India and China fought a short but brutal war over contested regions along their border. This war, which China won quite decisively, led to a complete breakdown in Sino-Indian relations. It also focused inordinate attention on 
International Relations and Strategic Studies. The period thus evokes very specific images and terms: the slogan Hindi-Chini bhai bhai (Indians and Chinese are brothers), the Panchsheela (Five Principles of Peaceful Coexistence) Treaty of 1954, the Bandung Conference of 1955, Tibet and the Dalai Lama’s flight to India in 1959, escalating border disagreements throughout the decade, and overshadowing them all: the war of $1962 .{ }^{5}$ Indeed, the war has come to serve as a teleological end-point for China-India studies of this period, which continue to be dominated by geopolitics and an obsession with the causes, course, and legacy of the war. ${ }^{6}$

But consider for a moment the kind of excitement that the birth of independent India and the establishment of the People’s Republic of China generated. In 1953, Frank Moraes (19071974), the first Indian editor of The Times of India and recently returned from a tour of China, wrote the following words:

By a quirk of fate Asia's two most densely populated countries, which are also neighbors, are the testing grounds for two differing and contending political philosophies. If China proves that her system of government ensures economic security to the vast mass of her people without detracting greatly from their sense of freedom, Asia will be lost to Communism. If India, on the other hand, demonstrates that democratic government can ensure not only economic security but individual liberty, then Asia will be won to democracy. What India and China are today doing is wrestling for the political soul of Asia (Moraes 1953: 207). ${ }^{7}$

The fate of the 'political soul of Asia,' as Moraes called it, captured the imagination of many minds in the 1950s. As two distinct political and economic experiments, China and India offered ideological and practical roadmaps for newly emergent post-colonial nations. This was precisely the logic that drove "The India Project" at the Center for International Studies at MIT. ${ }^{8}$ In the words of Wilfred Malenbaum, the economist who directed the project: “...countries, especially in Africa and Asia will be influenced in their own programs by what seems to be happening in 
these two lands. However much India and China disavow a state of competition between alternative paths for the transformation to growth, comparisons will be made everywhere, and lessons put into practice” (Malenbaum 1958: I2).

The two countries' prospects also fired the imagination of intellectuals and political radicals the world over. P.M.S. Blackett, the left-leaning Nobel laureate in physics, once confided to the Indian planner and statistician P.C. Mahalanobis that he could foresee India in the future holding its own or perhaps even bettering its conditions but China, by contrast, he was sure would race much further ahead. The British economist Joan Robinson made similar observations to Mahalanobis about China's prospects, coming away deeply impressed from a visit in 1953 (Mahalanobis to Pant, 24 June 1954, NMML, Papers of Pitambar Pant (190 LII), 14). ${ }^{9}$ Robinson would go on to visit China several times and was an enthusiastic and frequent communicator of her impressions and analyses (Robinson and Adler 1958, Robinson 1964, 1969, 1977). India too had its champions. The British biologist J.B.S. Haldane moved there in 1956 and eventually became a naturalized citizen in 1961. In a letter he wrote shortly thereafter, he explained: "I also happen to be proud of being a citizen of India, which is a lot more diverse than Europe, let alone the U.S.A, the U.S.S.R or China, and thus a better model for a possible world organisation” (Guha 2008: 769-770; Guha 2001: 134; Dronamraju 1987). And then there were those such as the radical American journalist Harold Isaacs who spent four years interviewing 181 prominent Americans from a variety of fields in a bid to understand elite American perceptions of newly emergent China and India (Isaacs 1980 [1958]).

Such comparisons and the implicit competition they frequently implied were the twin crucibles in which people's perceptions of 1950s China and India were forged. They influenced each country's self-perception as well, and found expression in attempts to extend scientific and 
cultural (and civilizational) influence across Asia. ${ }^{10}$ Less well understood, but no less significant, was the flourishing contact between China and India. And so, instead of 1962 and conflict, we find ourselves with a few other words: cooperation, contact, comparison, and competition. By taking them more seriously we can begin the process of decentering the teleology of 1962 and its overt emphasis on the evolution of Sino-Indian relations and instead approach afresh the possibilities of China-India history. ${ }^{11}$ Needless to say, this cannot just entail the celebration of rediscovery alone. Rather, the task is to think about China through India, or about India through China. In spirit, it is thus informed by three distinct yet kindred projects of historical critique and intervention: Paul Cohen’s ([1984] 2010) exhortation to abandon West-inflected histories of China, Dipesh Chakrabarty’s ([2000] 2007) call to provincialize Europe, and Kuan-Hsing Chen’s (2010) much more recent “Asia as Method” proposition. Beyond the immediate payoff of contributing to the histories of China and India, such an approach can generate fresh perspectives in at least two other historiographical areas. It can help write new histories of the Global South, especially of south-south interactions that go beyond Bandung-style political solidarities. At the same time, by exploring a range of linkages that fall outside of US- and Soviet-centric frameworks, it can also expand our understanding of an increasingly post-imperial and earlyCold-War world.

What follows is a demonstration of this proposition in two stages. First, I establish the 1950s as an important and yet largely neglected era in China-India history. Crucial to remedying this neglect is the creation of a chronological database that highlights not only how little we know, but also that such a salvage operation is a necessary condition for pursuing a more critical engagement with the decade. From there I proceed to a somewhat more detailed analysis of two 
case studies that emerge directly from the chronological reconstruction and demonstrate the kind of analytic purchase a study of 1950s China-India affords us.

The Study of China-India and 1950s as History

We stand at a particularly opportune moment to attempt such a task; for a few different reasons. The first of these has to do with the increased interest in recent years in studying China and India together. On the surface this appears to be solely a post-1990s phenomenon, as Chart 1 below suggests. Starting in the early 1990s there seems to have been a large increase in articles and books containing "China" and "India" or "Sino-India" in the title. ${ }^{12}$ By itself this is hardly surprising. The early 1990s were marked by Indian economic liberalization as well as by a renewed emphasis on export oriented growth in China following Deng's Southern Tour, policies that resulted in remarkable economic growth. Scholarly recognition of China and India's combined importance to the twenty-first century global economy has also proceeded apace (Friedman and Gilley 2005, Huang and Khanna 2003, Manuel 2015, Srinivasan 2006).

\section{[Chart \#1]}

An initial impression of unfettered rise in interest post-1990s, however, needs to be tempered by data about overall publishing relating to China and India. After all, the apparently dramatic shift in the 1990s could be part of a larger expansion in publishing as a whole. This does indeed seem to be the case: as Chart 2 shows, once we consider data on books and articles that contain China or India in their titles—a much larger universe — we see a similar pattern of

[Chart \#2] 
post-1990s increase. Combining the data from Charts 1 and 2 allows us to normalize publications with China and India in the title against the larger universe of publications with China or India in the title and thereby get a better sense of growth trends. Accordingly, Chart 3 tracks publications

[Chart \#3]

that have China and India or Sino-India in the title as a percent of publications that have China or India in the title. The picture that now emerges is not only one of recent growth, but also of a more dynamic sequence of changes. Using years with the highest (1962) and lowest (1986) rates as points of break, we arrive at three possible periods: 1947-62, 1963-86, and 1987-2013. Fitting a regression line for each period provides us statistically significant trends ( $\mathrm{p}=0.05$ ), with slopes that are positive, negative, and positive respectively. If we take publications whose titles contain China and India as an—admittedly unrefined and merely illustrative—heuristic for interest in the region, then our story becomes one of a growth in interest during 1947-62, followed by a period of gradual decline until 1986, only to witness a revival of interest since $1987 .^{13}$

While it is reasonable to expect that this renewed interest in China-India is primarily driven by contemporary concerns and located within various science and social science disciplines, the discipline of history has also experienced exciting new developments. Allowing for some generalization, most historical scholarship on China-India falls into one of three categories, which are nonetheless united by their temporal focus on the years prior to 1949 . The first of these we might label, tongue-somewhat-in-cheek, civilizational romanticism. In a recent interview, the Indian political psychologist Ashis Nandy articulated this approach quite succinctly: "China and India were not simply nation-states following the Westphalian model, they were also civilizations, civilizations which overlapped in a great measure. Culturally, China 
was partly inside India and India was partly inside China. Southeast Asia remains an example of that” (Kumar 2014). Such civilizational narratives, that take the ideas and concerns of contemporary nation-states and project them backward in time, are frequently coopted by nationalist projects of history writing and diplomacy. Leaders from both sides thus frequently speak of over 2000 years of contact, peaceful coexistence, and the transmission of Buddhism, focusing in particular on the activities of the Chinese monks Faxian 法显 and Xuanzang 玄牀 (Tan Chung 1998, Zhang 2006). ${ }^{14}$

The second category of China-India history takes more seriously this civilizational interaction. Properly dubbed Sino-Indology, in a 2012 tribute to the Chinese Sino-Indologist Ji Xianlin 季羡林 (1911-2009), Tansen Sen explained that Sino-Indologists aim to demonstrate that "interactions between India and China during the first two millennia CE were multifaceted, changing and more complex than previously acknowledged” (Sen 2012: 1, 6). ${ }^{15}$ Topics in SinoIndology have included the history of Buddhism and its spread, trade over the silk route, transfer of ideas and literary influences, the movement of technologies and goods (sugar, paper, porcelain), and much else (Xue 2006). Given the linguistic dexterity and philological mastery required to carry out such work, strong barriers to entry exist, making for a lively and productive but relatively small subfield.

The third area of China-India history focuses on the years 1800 to 1949 and its most dominant strain is intellectual history, with a focus on the writings and views of major Chinese and Indian intellectuals, in particular Dai Jitao 戴季陶, Mohandas K. Gandhi, Kang Youwei 康 有为, Liang Qichao 梁启超, Jawaharlal Nehru, Rabindranath Tagore, and Zhang Taiyan 章太 炎. ${ }^{16}$ Such research is particularly relevant in studies of Asian responses to the challenges of 
Western modernity and hegemony. Some work has also been done in other areas, such as on Indians who were deployed in China as part of the British Indian Army, on the medical aid that was offered to the communists during the 1930s, and on Sino-Indian diplomatic and economic history (Liu 2015, Mosca 2013, Sharma 2013, Thampi 2005a, Thampi 2005b, Thampi and Sharma 2015, Yang 2015). The latest and most exciting development is a new multi-year project on China-India history in the Republican period (1911-1949) (Tsui 2013).

Though the revival in enthusiasm for studying China-India history has yet to permeate the study of the 1950s, the decade itself has become a new frontier within the historiographies of both China and India. In other words, the 1950s now belong to history. By this I mean specifically the ways in which disciplinary divisions of labor have changed in recent years. In the China and India fields, 1949 and 1947 long marked boundaries that historians did not transgress. What lay beyond was almost exclusively the domain of political scientists, sociologists, economists, and anthropologists. But over the last fifteen years, spurred by the increasing openness of national and local archives and by the possibilities of oral history, historians have begun to offer new and compelling perspectives on the early years of the People's Republic of China (PRC) and independent India. ${ }^{17}$

In identifying these three factors—interest in China-India, the diversity of pre-1949 China-India historical scholarship, and the 1950s as history —and their salience for studying 1950s China-India history, it remains important to recognize a pervasive problem plaguing all such endeavors: the absence of strong China and India studies programs in the respective countries. The outcome is growing interest without language or area expertise in either country (Sen 2013). And while programs devoted to China and India do exist in the Western academy, they remain relatively isolated from each other; each set of scholars largely ignorant about the 
other field. Such a state of affairs exists at a time when historians themselves have begun to stress anew the importance of inter-Asian connections. In 2015, Harvard University Press published the first of a three-volume series that aims to survey "the historical, spatial, and human dimensions of inter-Asian connections” (Tagliacozzo, Siu, and Perdue 2015). And in his latest book on Asian traditions, Prasenjit Duara argues that we have reached a point where a global crisis of sustainability has superseded the need for nation-centric modes of analysis. His solution is to "revisit the alternative traditions from China and India, many strains of which have adapted to the unceasing circulations of modernity, to examine whether they allow a more viable cosmological foundation for sustainability” (Duara 2015: 2). This is an ambitious project and regardless of its viability, it points to a more basic need: to think creatively about how we conceive and execute projects in Asian history. And that brings us to the 1950s.

\section{A New Chronology for the 1950s}

One result of the neglect of the 1950s is that even basic chronologies of the period tend to privilege diplomatic interactions such as prime-ministerial visits, the signing of treaties, the arrival of ambassadors, and discussions concerning Tibet and the Sino-Indian border. While such events are no doubt important, a more holistic understanding of the decade can only begin with the reconstruction of more varied and inclusive chronologies. In 1961, Herbert Passin estimated that as many as 2,000 Indians may have visited the PRC during the previous decade (Passin 1961: 91). I have not encountered a similar estimate for Chinese visitors to India, but reports from the Indian Embassy in Beijing indicate that 5,833 Chinese traveled to thirty-three countries in 1955 alone (NAI 3(5)-R\&I/56, 4). Both Indian and Chinese visitors were motivated by a combination 
of curiosity, admiration, and suspicion. Unfortunately, the documentary record of this mutual appraisal, and of the varied contacts that formed at least a part of its basis, is rather lop-sided. The plentiful and ideologically varied published writings of Indian visitors make it hard to pinpoint an "Indian” view of China. Less is known of visiting Chinese delegations and individuals, in part because they were less prolific in producing detailed public reports of their activities. They all do, however, Chinese and Indian alike, suggest an enthusiastic and frequently serious engagement. ${ }^{18}$

The first task, therefore, is of historical reconstruction. A profitable way to begin this exercise is to chronicle the activities of the Friendship Associations in each country. In China, Friendship Associations were state-backed organs for promoting people-to-people contact with other nations. Their existence was formalized on 3 May 1954 by the establishment of the Chinese People’s Association for Cultural Relations with Foreign Countries. ${ }^{19}$ By that time, however, the China-India Friendship Association (CIFA; zhongyin youhao xiehui 中印友好协会) had already been active for two years. Among those presiding at its founding in Beijing on 16 May 1952 were the physicist, playwright, and Vice-Minister for Culture Ding Xilin 丁西林 (1893-1974), the sociologist and one-time CCP spy Chen Hansheng 陈翰笙 (1897-2004), and the celebrated author Lao She 老舍 (1899-1966). Ding, who was elected President of the Association, had led the first Chinese cultural delegation to India in late 1951 and would continue to visit the country over the course of the decade. Chen, who had spent two years in India during the mid-1940s, was elected vice-president of the Association and Lao She its director. In attendance were over 100 scholars, experts, poets, and artists, including the President of the Chinese Academy of Sciences, Guo Moruo 郭沫若 (1892-1978), the political scientist and 
minister of Education, Zhang Xiruo 张奚若 (1889-1973), the painter Wu Zuoren 吴作人 (19081997), and the Indologist Ji Xianlin 季羡林. India was represented by Vijaylakshmi Pandit (1900-1990), the leader of the Indian Cultural Delegation then visiting China (RMRB 1952a; FMA 105-00101-02; 105-00101-03; 105-00101-04; and 105-00884-01). Until its activities were suspended in 1962, the CIFA remained the principal agency through which cultural and other forms of contact and exchange with India were funneled. ${ }^{20}$

Unlike the CIFA, the India-China Friendship Association (ICFA; yinzhong youhao xiehui 印中友好协会) remained an informal organization whose leadership was populated by politicians and bureaucrats as well as by private citizens such as journalists, industrialists, artists, and academics. The first branch of the ICFA was founded in Calcutta on 12 February 1951, predating its Chinese analog by over a year (RMRB 1951). By 1956, R.K. Karanjia (1912-2008), editor of the weekly tabloid Blitz and the President of the Bombay branch of the ICFA, boasted that the "movement...had now spread all over the country... [and] there were at present 18 such associations all over India” (Karanjia 1956; TOI 1956a). But this was mostly haphazard and atomized growth. In a letter written to the bureaucrat T.N. Kaul (1913-2000) during the summer of 1955, K.M. Panikkar (1894-1963), India’s first ambassador to the PRC, had bemoaned precisely the "movement” like character of the Association: "[it] has a large number of constituents but there is no regular membership register and very few paying members.” Panikkar sought to "regularise the membership of the Association and to have a programme of work.” He proposed setting up a permanent office with paid staff that would coordinate four types of activities: publication of a quarterly journal, arranging exhibitions of Chinese arts and crafts, arranging film screenings, and promoting visits of leading unofficial personalities. Kaul was sufficiently convinced by Panikkar's plan that he sanctioned a one-time subsidy of INR 
5,000 (Panikkar to Kaul, 8 July 1955, NAI 1(41)-FEA/55, 6-7). By the following year, the ICFA was soliciting members in The Times of India (Picture 1.)

[Picture \#1]

Picture 1: Source: TOI December 1 1956, IV

According to one estimate, by early 1958 there had been approximately thirty CIFA delegations from China and forty ICFA ones from India (TOI 1958). While it is tempting to dismiss both CIFA and ICFA as mere tools of propaganda, their active participation in numerous instances of bilateral contact and the prominent press coverage they received render them particularly fruitful conduits through which to begin our process of reconstruction. Of course, there was also much contact not channeled through the Friendship Associations. How else might we explain Herbert Passin’s estimate for 1956, when “26 Indian delegations to China were counted and 33 Chinese delegations to India” (Passin 1961: 91)? Accordingly, our reconstruction includes information on the activities of ICFA and CIFA compiled from newspapers such as The Times of India, Renmin ribao, and Guangming ribao, in combination with information gleaned from two other sets of sources: contemporary journal articles that discussed Sino-Indian interactions (Fisher and Bondurant 1956; Passin 1961) and discoveries made in various archives and libraries in Beijing, New Delhi, Kolkata, Mumbai, and Toledo.

The result is an annual chronology that is strikingly different in comparison to existing chronologies of 1950s China-India history. ${ }^{21}$ To demonstrate what I mean, consider the example of one year-1956. The left hand column in Table 1 is reproduced from an edited volume on fifty years of China and India published in 2001 (Narayan 2001). I call this the standard chronology, for I believe it reflects the dominant mode of thinking about China-India in the 1950s: a focus on the border, on the military, and on visits of top leaders such as, as is the case 
here, Zhou Enlai. The right hand column is the result of the chronological reconstruction I have just outlined above. 


\section{DRAFT: DO NOT CITE OR CIRCULATE}

Table 1. Comparing Chronologies

\begin{tabular}{|c|c|c|}
\hline STANDARD CHRONOLOGY & 1956 & RECONSTRUCTION \\
\hline & January & $\begin{array}{l}\text { (1) Thirteen-member CIFA delegation led by Wu Han 吴晗 } \\
\text { arrives in Delhi; (2) Chinese student delegation attends } \\
\text { International Geography Seminar at Aligarh Muslim University; } \\
\text { (3) } 14 \text { Indian students suffering from tuberculosis undergo } \\
\text { treatment at Asian Students' Sanatorium, Beijing }\end{array}$ \\
\hline & February & $\begin{array}{l}\text { (1) CIFA delegation visits Bombay, then Ajanta, and Jabalpur; } \\
\text { returns to Delhi, where welcomed by ICFA, Delhi; (2) ICFA, } \\
\text { Bombay organizes second all-India conference }\end{array}$ \\
\hline & March & $\begin{array}{c}\text { (1) Nehru meets with CIFA Delegation before its departure; (2) } \\
\text { CIFA meeting in Beijing to prepare report of India visit; (3) } \\
\text { CIFA publishes report in RMRB on tour of India, Pakistan, and } \\
\text { Burma; (4) Chen Hansheng receives just returned CIFA } \\
\text { delegation in Beijing }\end{array}$ \\
\hline & April & $\begin{array}{l}\text { (1) Wu Han's 吴晗 write up about CIFA trip to India in RMRB; } \\
\text { (2) ICFA Delegation, led by Prof. Bapat, arrives in Beijing }\end{array}$ \\
\hline & May & $\begin{array}{l}\text { (1) CIFA hosts film night to celebrate fourth anniversary; (2) } \\
\text { Exhibition of the works of Indian film-maker Sharma (sha'erma } \\
\text { 沙尔玛) opens in Beijing }\end{array}$ \\
\hline & June & $\begin{array}{c}\text { (1) ICFA, Bombay organizes Chinese classes, } 11 \text { students enlist; } \\
30 \text { lectures spread over six months; (2) ICFA, Bombay } \\
\text { celebrates 2nd year of signing of Panchsheel; (3) Chinese } \\
\text { football team visits India, plays four matches in Calcutta and } \\
\text { Delhi, winning three }\end{array}$ \\
\hline \multirow[t]{2}{*}{ China Claims Wu Je (Barahoti) as Chinese Territory } & July & $\begin{array}{l}\text { (1) Ten journalists in two batches arrive in China; (2) Indian } \\
\text { Planning Commission Delegation led by Pitambar Pant arrives in } \\
\text { Beijing, stays until August; (3) Seven-member team to study } \\
\text { agrarian cooperatives arrives in Beijing, stays until late } \\
\text { September; (4) Six-member team under Deputy Minister M.V. } \\
\text { Krishnappa arrives in Beijing to study Chinese agricultural } \\
\text { planning and techniques, stays until August }\end{array}$ \\
\hline & August & $\begin{array}{l}\text { Three-member Chinese team led by a director of the Building } \\
\text { Research Institute (Beijing) visits Dehradun and Calcutta to } \\
\text { "study various techniques of using bamboo in house } \\
\text { construction,” focusing in particular on the "use of bamboo with } \\
\text { reinforced concrete" }\end{array}$ \\
\hline \multirow[t]{2}{*}{$\begin{array}{l}\text { (1) A Chinese Border Patrol crosses into the Shipki } \\
\text { pass in India; India Protests; (2) Indian } \\
\text { Parliamentary mission headed by M.A. Ayyangar, } \\
\text { speaker of the Lok Sabha, arrives in China }\end{array}$} & September & $\begin{array}{c}\text { (1) International Buddhist Delegation arrives in Beijing; (2) } \\
\text { Indian Parliamentary Delegation led by speaker of the Lok Sabha } \\
\text { Ayyangar 阿延加尔 arrives in Beijing }\end{array}$ \\
\hline & October & $\begin{array}{l}\text { (1) CIFA and its President Ding Xilin receive Indian } \\
\text { Parliamentary Delegation and an Indian Military Delegation; (2) } \\
\text { CIFA organizes a photo exhibit on India's first five year plan } \\
\text { (1951-1956); (3) Liu Shaoqi 刘少奇 sees off Indian delegation; } \\
\text { (4) Indian Military delegation received by Peng Dehuai 彭德怀 }\end{array}$ \\
\hline $\begin{array}{l}\text { A delegation of defense services led by General J.N. } \\
\text { Choudhari visits China }\end{array}$ & November & $\begin{array}{l}\text { (1) ICFA, West Bengal organizes memorial meeting in Calcutta } \\
\text { for Sun Yatsen (on his } 90^{\text {th }} \text { birth anniversary); (2) Zhou Enlai 周 } \\
\text { 恩来 welcomed in Delhi, on a 12-day visit }\end{array}$ \\
\hline $\begin{array}{l}\text { Premier Zhou Enlai visits India. Zhou says that as } \\
\text { regards Burma, China has accepted the McMohan } \\
\text { (sic) Line in formalizing the boundary. Recognition } \\
\text { of the same may be possible with India after } \\
\text { consultations with Tibetan authorities. }\end{array}$ & December & $\begin{array}{l}\text { (1) Calcutta receives Zhou Enlai, ICFA, West Bengal chapter, } \\
\text { throws reception; (2) Zhou chairs reception of ICFA delegation, } \\
\text { utters “Chinese and Indians are brothers” 中印人民是兄弟”; (3) } \\
\text { Zhou visits Indian Statistical Institute (ISI), Calcutta; (4) Chinese } \\
\text { State Statistics Bureau Deputy Director Wang Sihua 王思华 } \\
\text { (1904-1978) leads delegation of Chinese statisticians to ISI’s } \\
\text { 25th year celebration; delegation spends one month studying } \\
\text { statistical methods; (5) Chinese women's delegation visits India; } \\
\text { (6) ICFA opens wing called “ICFA Trade Information Bureau” }\end{array}$ \\
\hline
\end{tabular}


As the example of 1956 shows, our reconstructed chronology helps identify a range of new actors, agencies, events and processes, all heretofore neglected. The same is true for other years in the decade. Indeed, what emerges from the entire chronology is a veritable plethora of delegations, exhibitions, trade discussions, scientific exchange, film screenings, gifts, lectures, sporting encounters, student exchanges, and language training. Consider the following topical sample:

- Films: Chinese films were screened in India in April 1952 as part of an international film festival, well before the aforementioned 1955 exchanges. Films screened included White Haired Girl (1950; Bai mao nü 白毛女), the theatrical version of which became one of the eight model plays of the Cultural Revolution, and a documentary of the first National Day celebration, The Great Unity of China's People (1950; Zhongguo minzu datuanjie 中国民族大团结). Two other films completed the roster: Steel Warriors (1950; Gangtie zhanshi 钢铁战士) and Boundless Light (1949; Guangmang wanzhang 光芒万丈).

- Sports: An Indian table-tennis team visited China in September 1952. An Indian volleyball team visited China in October 1955 and played against a team from the Central Athletics Institute. The Chinese Olympic Eleven toured India in June 1956, playing four soccer matches. They won three and lost one, inflicting on Calcutta League champions Mohun Bagan their worst defeat against foreign opposition (1-8).

- Students: An agreement to send two exchange students from China and one from India was signed in October 1954. Eventually, China sent three students and India one. ${ }^{22}$ Ten additional Chinese students were in India by August 1955. In October that year, a delegation of 32 Indian teachers and students from ten universities traveled through China. And in January 1956, fourteen Indian students suffering from TB underwent treatment at the Asian Students' Sanatorium in Beijing. In June 1956, eleven students enrolled in a six-month Chinese language course offered by ICFA Bombay.

- Dance: Indian danseuses, the Laxman Sisters, visited China during March-April 1957; Uday Shankar's troupe also visited China that year. The Chinese dancer Yu Ying 于颖 was a member of the $1956 \mathrm{Wu}$ Han-led cultural delegation to India.

- Goa: China expressed strong support to India in its bid to recover Goa from Portuguese colonial control, even holding a rally in Beijing in August 1955 that was attended by 5000 people.

- Women's delegations: A Chinese women's delegation led by Minister of Justice Shi Liang 史良 (1900-1985) visited Indian in December 1956. 
- Notable individuals: The author of "Hindi-Chini bhai-bhai," the poet, actor, and onetime parliamentarian, Harindranath Chattopadhyaya (查托巴迪雅亚; 1898-1990), traveled to China in 1953. His collection of poems I Sing of Man (Wo gechang renlei 我 歌唱人类) was subsequently translated into Chinese (Chattopadhyay 1955). Madan Mohanlal Atal (爱德华; 1888-1957), the leader of the Indian medical team to China during the Second World War, visited China late in 1957. He fell ill and died there in early December. Following a memorial meeting in his honor in Beijing, some of his ashes were immersed in the Yellow River. Atal's unexplored legacy has long been overshadowed by that of his team-member, Dwarkanath Kotnis (柯棣华; 1910-1942).

- Notable animals: In May 1953, Nehru gifted an elephant named Asha (阿萨) to the children of China. She was put on display in the Western Suburb Park, the forerunner of the Beijing Zoo.

- Scientific and technological exchange: In January 1951, India became the first nonsocialist country to receive a delegation from the Chinese Academy of Sciences (CAS). Conference level exchanges continued in subsequent years and included engineers, hydrologists, pharmacologists, doctors, botanists, etc. The year 1956 heralded a qualitative transformation in these exchanges, which shifted to longer visits by delegations seeking to study specific subjects—hydrology, planning, agricultural techniques, statistical methods, etc. — in greater detail. ${ }^{23}$

Rebuilding a chronology that provides a fuller picture of 1950s China-India history, as noted earlier, is the first and necessary task. But it alone is insufficient. To substantiate the second part of my initial claim — to study one country through the other—I develop here two case studies, which through their variety suggest the distinct contributions they can make to the history of this period. The first deals with the question of bilateral trade between India and China, studies of which tend to ignore this decade in favor of starting with the normalization of relations in the early 1980s. The second focuses on the Indian demographer Sripati Chandrasekhar's visit to China in 1958. 


\section{Case Study I: Trade}

In 2014 China became India’s largest trading partner when measured by imports (second largest when measured by total trade) (The Financial Express 2014). While India plays a far less important role in China's global trade, their bilateral trade has grown over ten times during the last decade; it was \$7 billion in 2004 and touched \$73 billion in 2011. Bilateral discussions these days thus focus as much on trade as they do on the thorny issue of border demarcation. That trade enjoys such status should hardly be surprising. It has been at the heart of interactions between the two regions going back millennia. Even so, the celebrated premodern history of inter-regional trade sits in uncomfortable tension with its more fraught early-modern and modern analog. After all, it was imperialism driven trade in which opium and tea were central commodities that contributed to the linked impoverishment and stagnation of both regions.

To the extent that bilateral trade has returned to the fore in recent years, the focus of research is, quite understandably, on the post-1978 years (Srinivasan 1994; Rao 2014). And yet, trade offers a different vantage point from which to consider comparative and connected issues in the recent economic histories of both countries. Traditionally, this has been done via a focus on economic planning, with China’s first five year plan period (1953-57) frequently compared to India’s second five year plan period (1956-61). But for a limited discussion of border exchanges, trade is generally ignored under this approach and it should come as no surprise that our knowledge of China-India trade for most of the twentieth century remains gloriously vague. Admittedly, the quantum of this trade was small; each country had its own key trade partners during the first half of the century. India traded primarily with the United Kingdom and the wider Commonwealth. China’s trade had transitioned by the turn of the twentieth century, moving away from the UK and toward Japan and the United States. By the 1950s it had been 
restructured to fit within an international socialist economy undergirded by bilateral trade agreements (Kirby 2006). The volume of mid-century China-India trade thus remains hard to ascertain. ${ }^{24}$ According to unpublished UN estimates, of China's total exports of USD 1.13 billion in 1953, 46 million (4 percent) went to South Asia. India's corresponding figures were 1.12 billion and 3 million (0.3 percent). By 1959, China's total exports had grown to USD 2.21 billion, of which 66 million (3 percent) went to South Asia. India’s corresponding figures read: 1.31 billion and 16 million (1.2 percent). ${ }^{25}$ But a focus on the quantum of trade is only one among multiple ways to approach the subject. Our reconstructed chronology offers useful clues.

Throughout the 1950s, interlocutors from both countries recognized the importance of trade, in its material as well as symbolic forms. "Economic and Trade Cooperation between India and China” had been on the agenda of the ICFA at its first annual meeting in Bombay in June 1952 (TOI 1952). And harkening back to trade’s central role in Asia’s subjugation, Governor of Bombay Dr. Harekrushna Mahtab encouraged bilateral trade but cautioned against getting “caught once again in the 'Western Trap’” (TOI 1956a). In similar fashion, Kong Yuan 孔原 (1906-1990), the leader of a twenty-nine member trade delegation to India and Indonesia in 1954, observed that it was the common aspiration of not just China, India, and Indonesia, but all Asian and African countries to increase mutual trade and thereby overcome the historic effects and contemporary manifestations of imperialism (Kong 1955). Kong's trade delegation was on the road from June to November and their negotiations in India culminated in the signing of a Trade Agreement on 14 October 1954. This two-year agreement followed close on the heels of the much more celebrated and memorialized Panchsheel Treaty, which had formalized border trade between Tibet and India and espoused the Five Principles of Peaceful Coexistence (Singh 1998), and therefore points to a much broader conception of China-India trade. It listed a whole range of 
goods that each country would export to the other. Chinese exports included cereals, machinery, minerals, silk, animal products, paper and stationery, chemicals, and oils; Indian exports included grams, rice, and pulses, unmanufactured tobacco, minerals and ores, wood and timber, fibers, textiles, skins, chemicals, and machinery. ${ }^{26}$ The treaty’s impact was immediate: trade in 1954-55 witnessed a seven-fold increase over the previous year, though it constituted a rather small share of India's global trade at 1.2 percent (Mody 1956).

In addition to treaties, industrial exhibitions were the most tangible manifestation of trade related activities between the two countries. The first Chinese exhibition took place in Bombay in the spring of 1952. It was part of a two country tour (India and Pakistan) that lasted 80 days and involved a combined total of 4.5 million visitors (RMRB 1952b). A second Chinese exhibition took place in Delhi in the winter of 1955 (Chen 1957). Traveling the other way, an Indian exhibition held in Beijing during four weeks in September and October 1957 was touted as the country's largest foreign exhibition. Containing products made by public and private enterprises, it occupied 10,400 square meters in the Western Suburbs Exhibition Hall (xijiao zhanlanhui 西郊展览馆) and attracted nearly one million visitors. Walking into the main hall, visitors were greeted by a variety of automobiles, including a double-decker bus, and other large industrial goods, before encountering handicrafts, textiles, and light industrial goods in adjoining rooms (Picture 2).

\section{[Picture \#2]}

Picture 2: Indian exhibition, Western Suburbs Exhibition Hall, Beijing Source: Guangming ribao 20 September 1957

Newspaper reports suggest that the exhibition was a roaring success. The People's Daily carried a detailed laudatory review by Chen Hansheng and the Guangming Daily provided 
enthusiastic coverage with numerous photographs. Internal departmental memos, however, offer a more sober appraisal. They note that footfall had been less than expected; many visitors were unimpressed by the scale and quality of the exhibition (bu fengfu 不丰富), racing through it in a mere thirty minutes. The memo did concede that the Rectification and Anti-Rightist campaigns then rampant across most work units may also have contributed to the lukewarm reception, but insisted that this was a secondary, relatively minor factor (Chen 1957, Wen 1957, Guangming ribao 1957, RMRB 1957, BMA 002-020-00100: 13-16).

The most interesting and intriguing trade related clues, however, are not state-backed initiatives such as treaties and exhibitions, but those instances where the boundary between the official and unofficial blurred. Late in 1956, the ICFA established a special wing called the Trade Information Bureau, whose purpose was to facilitate trade between the two countries. In an announcement, they explained:

The main objective of this Wing is to act as Liaison between our Importers and Exporters and the Chinese Importing Associations and Houses. The Wing will give them all the available information on trade matters and will also offer its services to solve problems and difficulties experienced in exchange, deliveries, standard of goods, shipping prices, etc. This Wing will be able to take up matters like introducing Indian exporters and importers to their counterparts in China and vice versa (Mody 1956).

Firms and companies interested in pursuing trade with China were encouraged to contact the Wing at the ICFA, Bombay headquarters located in Neelam Manzil on Lamington Road. K.K. Mody, the treasurer of the (Bombay) ICFA and author of the article within which this announcement was placed, framed this bilateral trade within explicitly geopolitical and interAsian contexts. He explained that the recent Suez Crisis had shown India that it couldn't rely on trade with the West alone; had the war become a protracted one, the canal's likely prolonged 
closure would have had a perceptible effect on India. Furthermore, by turning toward Asian partners, Mody emphasized "there is also a great possibility of our getting a fair deal for our products and paying fair prices for our imports, unlike some of the recent experience with some Western countries” (Mody 1956). Further work will be needed to uncover the records of this Wing and the firms and companies in India and China that it might have been in touch with. On the Chinese side, the Ministry of Foreign Trade (duiwai maoyibu 对外贸易部) was most certainly involved. For instance, between February and April 1958 it responded to an Indian request for Chrysanthemum (juhua 菊花) seeds by sending over a large variety of seeds (BMA 002-010-00078).

Indian enthusiasm for trade did not escape the notice of visiting Chinese delegations. In 1956, the historian and vice-mayor of Beijing Wu Han 吴晗 (1909-1969) led a twelve-member cultural delegation on a six-week tour of India. In whistle-stop fashion, they covered nearly 10,000 miles and visited 42 cities (BMA 002-008-00068: 19-20). In Madras, the delegation was struck by the spontaneity and warmth (zidong yao jiedai women 自动要接待我们) of the descendants of local royalty (tuwang houyi 土王后裔) they encountered. Further north in Ahmedabad, the local Rotary Club (an organization of capitalists with ties to the US, the delegation dutifully noted) had requested a meeting even though it was not part of the formal itinerary. When told that the delegation could not spare the time, the Club had insisted that at least one delegate be sent, even if only for twenty minutes. In Kanpur, one of the city’s prominent industrialists categorically explained to the delegation members that Indian capitalists were especially interested in promoting Sino-Indian trade. This sequence of discrete encounters culminated in Bombay at the second All-India ICFA meeting, where the central theme was "how 
to strengthen Sino-Indian trade relations.” The delegation noted that many of ICFA Bombay's

members were capitalists themselves. ${ }^{27}$ It is unclear if there was any appreciation of the fact that many major Indian industrial houses traced their origins to the opium trade. Even so, these experiences clearly took the delegation by surprise: the attitude of India's capitalists and landlords was a subject deserving of further attention, they concluded (zhidi women zhuyi 值得 我们注意) (BMA 002-008-00068: 22).

1950s China-India trade deserves our attention too. The discussion here points to several fruitful directions for future research: the India-Tibet border trade and its relationship to ChinaIndia trade as a whole, the role of public and private firms and producers, the nature and quantum of goods traded, and the means and routes of transportation. Just as significant will be an analysis of the symbolic purpose served by both the actual trade and by the discourse surrounding it. An initial focus on India and China can in time be expanded to include other countries as we arrive at new perspectives on the role of trade in the twentieth century history of Asia, and the Global South more broadly, adding material and economic histories to existing political ones.

Case Study II: An Indian demographer in China

If the case of trade alerts us to the importance of institutional, entrepreneurial, and material connections between China and India, the case of Sripati Chandrasekhar’s 钱得拉素卡尔 (19182001) four-week visit to the PRC in November and December 1958 highlights the possibilities of individual contacts. At the time of his visit, Chandrasekhar was a professor of economics at Annamalai University and the director of the Indian Institute of Population Studies in Madras 
and already an internationally renowned demographer. ${ }^{28}$ He parlayed his boots-on-the-ground experience into short-lived but extensive fame as an authoritative expert on contemporary China and its "Population Problem,” delivering lectures in far flung places including Hong Kong, Taiwan, India, the United States, and various African countries (SCP B14 F20). The visit resulted in a slew of articles, important among which was a four part series in the Calcutta-based The Statesman that was subsequently syndicated by Associated Press (SCP B37 F48: 45, 47, 51, 53). Chandrasekhar also wrote four books in the immediate years after his visit (Chandrasekhar $1959,1960,1961,1962) .{ }^{29}$

Chandrasekhar's visit marked the first time that a trained demographer had the opportunity to visit the PRC. That the demographer happened to be from India, the second largest nation in the world, and the first developing nation to have instituted family planning programs, makes it doubly interesting. At the same time, Chandrasekhar was trained in and sympathetic to the United States, had worked at the UN, and had a deep-seated interest in

\section{[Picture \#3]}

Picture 3: Chandrasekhar and his American wife, Anne, around the time of his visit to China Source: SCP B37 F48: 65

population control, all of which would make him suspicious in the eyes of his Chinese hosts. Also noteworthy is the fact that the visit took place during the early months of the Great Leap Forward (1958-61) and provides an eye-witness account of the early enthusiasm for the campaign. Finally, as an instance of private travel and research, it also reminds us of the diversity of these episodes. Today, however, this episode is largely forgotten. And yet, by mining not just Chandrasekhar's published works but also his personal papers and Chinese internal documents, we can gain fresh insights into such subjects as birth control in 1950s China, the 
Great Leap Forward, and, not least, the Chinese Foreign Ministry's handling of potentially troublesome guests.

The tour itself, however, nearly did not materialize. Chandrasekhar had been keen to visit China since the late 1940s, but had wanted to do so as a State Guest and not in a private capacity or as a member of a delegation. This had made things difficult and the trip only became possible after several rounds of negotiations. ${ }^{30}$ Chinese officials were understandably wary of Chandrasekhar's connections to the United States and his liberal sympathies. In the end, the Foreign Ministry and the Institute of Foreign Affairs (waijiao xuehui 外交学会) informed the Chinese Embassy in Delhi that they could "only agree to a visit made by him in a private capacity, with all costs personally borne by him” (Telegram, 16 April 1957, FMA 105-00887-01: 11). This decision was relayed to Chandrasekhar and infuriated him to no end (Ma Mu-ming (First Secretary) to Chandrasekhar, 3 May 1957, SCP B14 F20). In a letter to K.M. Panikkar, India’s former ambassador to the PRC, he complained: “... [the letter from the Chinese] is most unhelpful as you can see. It says that I can go to China, pay my expenses; as if all this correspondence is to get a formal permission to visit China. All sorts of people go to China as State Guests and the question of my going at my expense does not arise” (Chandrasekhar to Panikkar, 8 May 1957, SCP B14 F20). Chandrasekhar went on to beseech Panikkar’s intervention. But the Chinese held firm and after additional rounds of letter-writing, they reiterated: "[you are]...welcome to go to China on a private visit and on [sic] your own expenses" (Ma Mu-ming to Chandrasekhar, 21 August 1958, SCP B14 F20). Much as this snub hurt Chandrasekhar's sense of self-worth, corresponding Chinese internal memoranda provide finegrained insight into the handling of potentially problematic guests. Consider the following guidelines pertaining to his visit: 
- Be polite but propagandize the Great Leap Forward; explain that China has no population problem; use him to understand the situation in India.

- The State Statistics Bureau and the Foreign Ministry will handle most of his travel affairs.

- No officials are to receive or send him off (this is not an official visit).

- Only arrange one small [dinner] party in his honor (one table).

- Schedule no meetings with political leaders (instead consult attached list of people in various bureaus).

- Disseminate no news/information about the visit. Take photos, but only for record keeping.

- Finally, he must pay for everything. (FMA 105-00887-01: 28-30) ${ }^{31}$

In spite of this cool attitude, Chandrasekhar spent a hectic month in the PRC. He visited a wide variety of institutions across several cities and met with numerous prominent Chinese experts. The majority of these activities are summarized below: ${ }^{32}$

$\begin{array}{lll}\text { Cities: } & \begin{array}{l}\text { Beijing Guangzhou Hangzhou } \\ \text { Shanghai Tianjin }\end{array} & \begin{array}{l}\text { Harbin } \\ \text { Zhengzhou }\end{array} \\ \text { Institutions: } & \text { China Institute of Agricultural Research, Shanghai } \\ & \text { A Maternity and Children's Hospital } \\ & \text { Harbin Medical College } \\ & \text { Peking University, Beijing } \\ & \text { People’s University, Beijing } \\ & \text { Shanghai Academy of Social Sciences } \\ & \text { Sun Yatsen Medical College, Guangzhou } \\ & \text { Tsinghua University, Beijing } \\ \text { Women’s Education Center, Shanghai } & \text { Wuhan Medical College, Wuhan } \\ \text { Factories: } & \text { Contraceptive Factory, Shanghai } \\ & \text { Iron and Steel Complex, Wuhan } \\ \text { Jute factory } & \text { Milk Rubber Factory, Canton } \\ \text { Steam Turbine Manufacturing Factory } & \text { Wuhan Heavy Machine Building Factory }\end{array}$




\author{
People: Bai Jianhua 白建华 B Chen Da陈达 \\ Chen Hansheng 陈翰笙 Dai Shiguang 戴世光 \\ Kung Chi Chang Lo Keng Mo \\ Mr. Pan (Interpreter) Shu Kang \\ Wu Yun Fu \\ Exhibits: Agricultural Exhibit \\ Birth Control Exhibition, Beijing \\ National Exhibit of Industry and Commerce \\ Communes: Chi Yi Lin (outside Zhengzhou) \\ Sin Chin San (Yamen Ko village, near Beijing)
}

Chandrasekhar came away from the trip with strongly negative views of Chinese society and its prospects for continued population growth, which, he was convinced, would result in attempts at militaristic expansion (Chandrasekhar 1961: 139). These views are interesting for what they tell us about Cold War constructions of the Chinese other, but they were also rightly criticized by contemporary reviewers for being too simplistic and perhaps even ideologically overdetermined (Han Suyin 1962). ${ }^{33}$ Once we set aside Chandrasekhar's pronouncements about the prospects and perils of 'Red China,' there remains, however, much else worthy of discovery and analysis.

Take the case of population, Chandrasekhar's principal area of interest. During his time in the PRC, he visited numerous hospitals, where he was introduced to contemporary approaches to birth control. He was told that birth control was recommended to promote better health among the Chinese people. To achieve this, women were permitted to carry out postpartum sterilization. In other instances, women were given diaphragms and an applicator jelly. If they wanted birth control for long periods, a "ring is inserted into the uterus with an introducer and taken out after 
two or three years with a remover.” As for men, Chandrasekhar observed that sometimes they used "sheaths" (condoms). He concluded that "both sheaths and diaphragms are rather unpopular. The ring and sterilization are popular. Vasectomies are also performed but men don't like it. But women like post-partum sterilization.” Chandrasekhar was provided with samples of contraceptive devices and told that they were made locally in factories in Guangzhou, Shanghai, and Wuhan. He wrote in his diary that they "look like good products. Extremely cheap—a sheath costs one naya paisa. A diaphragm and jelly costs Rs. 2 in purchasing power exchange. They are given free or charged a trifle of the nominal price.” Given the Great Leap Forward’s demand for steel, he was also told about introducers made from bamboo, which he found "well done and extremely ingenious” (SCP B19 F43: 7-8).

Chandrasekhar was taken to two major factories making birth control devices, in Shanghai and Canton. He had already been told that an estimated “450,000,000 condoms, 300,000 diaphragms and 1,950,000 tubes of jelly were produced in 1957-about six times more than were produced in the previous year” (SCP B19 F43: 56). ${ }^{34}$ At these factories, he was able to witness their production. The contraceptive factory in Shanghai, for example, employed 200 workers, sixty percent of whom were women. Average wages were around seventy yuan and all raw materials were sourced from within China; the rubber coming mainly from Southern Hainan. The factory had originally been established in 1938 under the Nationalists but had ceased operations in 1946, only to have been started up again in 1952. By 1958, it was making about five million sheaths (condoms) and about 50,000 diaphragms. Chandrasekhar was impressed with the production methods he observed, finding them simple enough for the Government of Madras or a private manufacturer in India to emulate. He went on to observe: 
The sheaths [condoms] in China sell for 3 cents each - roughly 3 n.P. each, treating the yuan as equivalent to a rupee. The sheaths come in two sizes and the diaphragm in 5 sizes...Some of these are exported to Asian countries. The demand for diaphragms is not as great as the demand for sheaths. Saw a lot of unmarried girl workers testing sheaths by blowing. They began to giggle when they saw me watching their testing! (SCP B19 F43: 90.)

Towards the end of his travels, Chandrasekhar also visited the Canton Milk Rubber Factory, which was significantly larger than the Shanghai factory and employed 1,200 workers. The rubber was again sourced from Hainan. But unlike the Shanghai factory, it had been built from scratch in 1955. In 1957, it had produced sixty million sheaths, each of which was sold to peasants by the government at subsidized rates (2 cents vs. 4). When asked about how information about these products was disseminated, he was informed that the products were not advertised but peasants knew about them nonetheless and could purchase them in village shops. He also learned that "contraceptives for men are in greater demand than contraceptives for women. The peasants use them 5 or 6 times before they throw a sheath away.” In order to allow reuse, a sterilizing powder was provided with each sheath (SCP B19 F43: 96).

These are just a small sampling of the kind of detail that exists in these materials. Chandrasekhar's observations raise a whole variety of questions about the practice of birth control during the late 1950s, especially the manufacture and materiality of contraceptive devices and the micro-politics of their use. Pursuing them would allow us to look beyond the discursive analysis of policy documents and government manuals and move away from macro concerns to reconstruct a fuller history of birth planning and control in 1950s China. In the otherwise rich and diverse field of population studies of China, we do not yet possess this particular history. Writing in the late 1970s, Leo Orleans had noted: "China also had to make sure that the health establishment charged with the dissemination of birth control information would have at its 
disposal a plentiful supply of effective and acceptable contraceptives—a building block not in place until the 1960s” (Orleans 1978: 8). In similar fashion Thomas Scharping has observed that "the production of modern contraceptives began in 1956," but then dismissed this production as too small to have had any significant impact (Scharping 2003: 105). ${ }^{35}$ Studies such as those of Scharping and Tyrene White (2006: 21-26) approach birth planning and population control during this period largely from the perspective of the speeches of leaders and official documents and do so primarily as brief background en route to more substantive discussions of later decades. Even the work of Susan Greenhalgh and Edwin Winckler (2005: 64-74), which offers thus far the most meticulous and insightful discussion of contraception during the 1950s, confines itself largely to the discursive and policy field. By pursuing clues found in the Chandrasekhar materials, additional research on the materiality and production of contraceptive devices can complement existing scholarship and significantly enhance our understanding of birth control during this period in China's history.

\section{Conclusion: A New Agenda}

The chronology and the two case studies discussed here are scratches on a vast surface. Nonetheless, they demonstrate that an approach that takes seriously cultural, scientific and economic life leads to different sources and different historical arguments from an approach focused on political (and especially high political) life. China-India history of the 1950s, to the extent that it has been done, remains mired in concerns related to border demarcations and the war of 1962. The price has been the disavowal of other important lines of historical inquiry. But by displacing (not dismissing) our mono-ocular focus on 1962 and widening our lens to also 
include moments of contact, comparison, cooperation, and competition, we can offer fresh insights in a variety of historical fields. For starters, such a study of China-India can enrich our understanding of both Chinese and Indian history. But just as significant are the broader methodological implications of another form of displacement. Studying one country in the Global South through another also in the Global South decenters (again, does not dismiss) the West when writing histories of the twentieth century. Such an approach can lead to the (re)discovery of important episodes and offer exciting new interpretations of recent history.

In the China-India case, more specifically, the chronology can serve as a useful point of departure. Future research topics can include writings on China and India, especially popular and specialist perceptions of the prospects of each country; bilateral visits of intellectuals and practitioners; scientific contact and cooperation; the activities of the Friendship Associations; literary and cultural activities, including the screening and reception of films and the translation and reception of texts; competition for influence in places like South-East and Central Asia; exploration of materials in vernacular languages; and the influence of Chinese communism (Maoism) on Indian communist movements. Were we to pursue these and other topics, I predict we will discover new and important perspectives on Chinese, India, Asian, and international history, all of which will crucially inform how we approach the challenges of the twenty-first century.

Writing thirty-odd years ago, Seth closed his China travelogue with these words: “...to learn about another great culture is to enrich one's life, to understand one's own country better, to feel more at home in the world, and indirectly to add to that reservoir of individual goodwill that may, generations from now, temper the cynical use of national power” (Seth 1987: 178). Revisiting the 1950s in all their richness and complexity may thus yield not just a more 
multifaceted history but also produce that most elusive of diplomatic outcomes: an improvement in Sino-Indian relations.

\section{ACKNOWLEDGMENT}

I would like to thank Jeffery Wasserstrom and the four anonymous reviewers for their incisive and thorough feedback on earlier drafts of the paper. This paper originated in a talk I delivered at Northeastern University in the fall of 2014. I am grateful to Philip Thai for suggesting my name and to Gavin Shatkin for the invitation. A modified version was subsequently presented at the Center for Policy Research in New Delhi in July 2015; thanks, in particular, to the interest shown by Partha Mukhopadhyay, Pratap Bhanu Mehta, and Srinath Raghavan. Liz Perry, Emma Rothschild, Tansen Sen, Arne Westad, Rohit De, Mark Elliott, Partha S. Ghosh, Gal Gvili, Matthew Connelly, and Richard So generously read various versions of this paper, in part or whole, offering much needed criticism and encouragement along the way. Suqin Hou provided expert research assistance in collecting bibliometric data from WorldCat and other databases. Thanks also to Paul Vierthaler, Shannon Stewart, Donald Sturgeon, and Ameet Morjaria, who discussed the data with me.

\section{LIST OF REFERENCES}

\section{Archives}

BMA BeiJing Municipal Archives, BeiJing

FMA Foreign Ministry ARCHIVES, BEIJING

NAI NATIONAL ARCHIVES OF INDIA, NEW DELHI

NMML NeHru Memorial Museum and Library, NeW Delhi

SCP SRIPati Chandrasekhar Papers, MS 189, The Ward M. Canaday Center

for Special Collections, The University of Toledo, OHio

\section{Other References}

AiYar, Pallavi. 2010. Smoke and Mirrors-An Experience of China. New Delhi: Fourth Estate. Avasthi, Yogesh. 2014. “First Lady Springs Awara Surprise.” Ahmedabad Mirror, September 18.

BAshford, Alison. 2014. Global Population: History, Geopolitics, and Life on Earth. New York: Columbia University Press.

BhattacharJya, Satarupa. 2014. "Hindi Film Power." China Daily USA Online, August 28. BIDWAI, PrAful. 2015. The Phoenix Moment: Challenges Confronting the Indian Left. New Delhi: Harper Collins.

BLACKMER, Donald L.M. 2002. The MIT Center for International Studies-The Founding Years, 1951-1969. Cambridge: MIT Center for International Studies. 
Bowles, Chester Bowles. 1971. Promises to Keep: My Years in Public Life, 1941-1969. New York: Harper \& Row.

Brownlee, Kimberly and Daniel M. Johnson. 2004. “The Papers of Dr. Sripati Chandrasekhar.” Population Review Volume 43, Number 1, 76-81.

Chakrabarty, Dipesh. 2007 [2000]. Provincializing Europe: Postcolonial Thought and Historical Difference. Princeton: Princeton University Press.

Chandrasekhar, Sripati. 1959. China's Population: Census and Vital Statistics. Hong Kong: Hong Kong University Press

—. 1960. Decade of Mao's China: A Survey of Life and Thought in China Today. Bombay: Perennial Press.

—. 1961. Red China: An Asian View. New York: Praeger.

—. 1962. Communist China Today. Bombay; New York: Asia Publishing House.

CHATTOPADHYAY, HARINDRANATH 哈. 查托巴迪雅亚. 1955. Wo gechang renlei 我歌唱人类 [I Sing of Man]. Beijing: Zuojia chubanshe.

CHEN, HANSHENG 陈翰笙. 1957. “Cong yindu zhanlanhui tan zhongyin maoyi” 从印度展览会 谈中印贸易 [The Indian Exhibition and Sino-Indian Trade] Renmin ribao 19 September 1957: 5.

Chen, KuAn-Hsing. 2010. Asia as Method: Toward Deimperialization. Durham: Duke University Press.

Cohen, Paul A. 2010 [1984, 1996]. Discovering History in China: American Historical Writing on the Recent Chinese Past, with a New Introduction by the Author. New York: Columbia University Press.

DAI, CHAOWU 戴超武. 2014. “Zhongyin bianjie wenti xueshushi shuping (1956-2013) 中印边 界问题学术史述评 (1956-2013)” [The Sino-Indian Boundary Questions: A Critical Historiography (1956-2013)]. Shixue yuekan 10, 91-115.

DE, Rohit. 2013. “The Republic of Writs: Litigious Citizens, Constitutional Law and Everyday Life in India (1947-1964).” PhD Dissertation, Princeton University.

Dronamraju, Krishna R. 1987. "On Some Aspects of the Life and Work of John Burdon Sanderson Haldane, F.R.S., in India,” Notes and Records of the Royal Society of London, Vol. 41, No. 2 (Jun.), 211-237.

DuARA, Prasenjit. 1995. Rescuing History from the Nation: Questioning Narratives of Modern China. Chicago: University of Chicago Press.

—. 2010. "Civilization and Realpolitik," in India China: Neighbors Strangers, edited by Ira Pande, 20-33. New Delhi: Harper Collins.

—. 2015. The Crisis of Global Modernity_Asian Traditions and a Sustainable Future. Cambridge: Cambridge University Press.

FINANCIAL EXPRESS, THE. 2014. “China emerges as India’s top trading partner: Study.” March 2.

Fisher, Margaret W. And Joan V. Bondurant. 1956. "Review Article: The Impact of Communist China on Visitors from India.” The Far Eastern Quarterly 15, no. 2 (February), 249-265.

Freidman, EdWARD AND BRUCE GILley, Eds. 2005. Asia's Giants-Comparing China and India. New York: Palgrave, MacMillan.

GHOSH, ARUnABH. 2016. “Accepting difference, seeking common ground: Sino-Indian statistical exchanges 1951-1959,” BJHS Themes, Volume 1, 61-82.

Ghosh, Atish. 2004. “Bollywood Ties Across Borders.” Deccan Herald Sunday, August 8. 
Gould, William, Taylor C. Sherman, and SARAh Ansari. 2013. "The Flux of the Matter: Loyalty, Corruption and the 'Everyday State' in the Post-Partition Government Services of India and Pakistan.” Past and Present 219 (1), 237-279.

Greenhalgh, SusAn And EdWIn A. WincKler. 2005. Governing China's Population: From Leninist to Neoliberal Biopolitics. Stanford: Stanford University Press.

GUANGMING RIBAO. 1957. “Zouxiang xiandaihua de yindu gongye...走向现代化的印度工业...” [India’s industry moves towards modernization...]. September 23, 3

GuHA, Ramachandra. 2001. An Anthropologist Among Marxists and Other Essays. Hyderabad: Orient Blackswan.

—. 2008. India After Gandhi: The History of the World's Largest Democracy. Pan Macmillan.

GuPTA, KRISHNA PRAKASH. 1972a. "Indian Approaches To Modern China-I: A Socio-Historical Analysis,” China Report Vol. VIII, No. 4 (July-Aug.), 29-51.

—. 1972b. "Indian Approaches To Modern China-II: A Socio-Historical Analysis,” China Report Vol. VIII, No. 5 (Sept.-Oct), 38-57.

Han, Suyin. 1962. "Red China, an Asian view,” Eugenics Review, April, 54(1), 41-42.

Howe, WiLliam L. 2005. “Condom Industry Global Trends.” Accessed 10 October 2015 at: http://www.oemcondom.com/html/CondomIndustry/36.html

Huang, YAsheng And TARun KhannA. 2003. “Can India Overtake China?” Foreign Policy, no. 137 (July-August), 74-81

IndiA, GOVERNMENT OF. 1956. Report of the Indian Delegation to China on Agricultural Planning and Techniques. New Delhi: Government of India, Ministry of Food and Agriculture.

-. 1957. Report of the Indian Delegation to China on Agrarian Cooperatives. New Delhi: Government of India, Planning Commission, May;

- 1959. Report of the Indian Delegation to China for Study of Irrigation and Water Conservancy Projects during January-February 1959. New Delhi: Government of India, Ministry of Food and Agriculture.

INDiA TODAY ONLINE. 2011. “From RK to SRK, Bollywood forever in China.” September 28.

IsAACS, HAROLD R. 1980 [1958]. Scratches on our Minds-American Views of China and India. Armonk: M.E. Sharpe, Inc.

KARANJIA, R.K. 1956. “Genuine Friendship of Culture and Faith,” TOI December 1, I.

KirBY, William C. 1990. "Continuity and Change in Modern China: Chinese Economic Planning on the Mainland and on Taiwan, 1943-1958.” Australian Journal of Chinese Affairs 24 (July), 121-141.

—. 2006. "China's Internationalization in the Early People's Republic: Dreams of a Socialist World Economy." The China Quarterly 188 (2006), 870-890.

KONG, YUAN 孔原. 1955. "Fazhan zhengchang maoyi laiwang he jingji hezuo shi yafei remin de gongtong yuanwang 发展正常贸易来往和经济合作是亚非人民的共同愿望” [The development of regular trade and economic cooperation is the common aspiration of Asian and African peoples]. Renmin ribao April 25, 3.

Kumar, Amitava. 2014. "India's most famous psychologist looks on the bright side about Sikhs, Muslims, Hindus_-and even the Chinese.” Quartz Online, November 10.

Leighton, Christopher R. 2010. Capitalists, Cadres, and Culture in 1950s China. PhD Dissertation, Harvard University.

Li, Choh-Ming. 1962. The Statistical System of Communist China. The University of California Press. 
LiU, Andrew B. 2015. “The Two Tea Countries: Competition, Labor, and Economic Thought in Coastal China and Eastern India, 1834-1942.” PhD Dissertation, Columbia University.

Malenbaum, WilfReD. 1958. “East and West in India's Development-Preliminary Draft.” Econ. Dev. Program, Project No., 7674, NPA Competitive Coexistence Study, Center for International Studies, MIT, Cambridge. Link: http://hdl.handle.net/1721.1/85144.

Manuel, Anja. 2015. This Brave New World-India, China and the United States. New York: Simon and Schuster.

Mehra, Parshotam. 2006. Essays in Frontier History: India, China, and the Disputed Border. New Delhi: Oxford University Press

Mishra, PANKAJ. 2012. From the Ruins of Empire: The Intellectuals Who Remade Asia. New York: Farrar, Straus and Giroux.

Mody, K.K. 1956. “Trade and Commerce Between India and China.” The Times of India, December 1, II.

Moraes, Frank. 1953. Report on Mao’s China. New York: The MacMillan Company.

Mosca, Matthew. 2013. From Frontier Policy to Foreign Policy: The Question of India and the Transformation of Geopolitics in Qing China. Stanford: Stanford University Press

NARAYAN, RAVIPRASAD. 2001. "Chronology," in Crossing a Bridge of Dreams: Fifty Years of India-China, edited by G.P. Deshpande and Alka Acharya, 497-499. New Delhi: Tulika Press.

Orleans, LeO. 1978. "Planning Births in China: Trends and Traumas,” in Chinese Approaches to Family Planning, translated by Robert Dunn, edited by Leo A. Orleans, 3-21. New York: M.E. Sharple, Inc.

PAssin, Herbert. 1961. “Sino-Indian Cultural Relations,” The China Quarterly, no. 7 (JulySeptember), 85-100.

Rajagopalan, Sudha. 2008. Leave Disco Dancer Alone: Indian Cinema and Soviet MovieGoing after Stalin. New Delhi: Yoda Press.

—. 2009. Indian Films in Soviet Cinemas: the Culture of Movie-going after Stalin. Bloomington: Indiana University Press.

RAO, Nirupama. 2014. “The Politics of History: India and China, 1949-1962.” Third Dr. S. Gopal Annual Memorial Lecture, King’s India Institute, King’s College London; available at: https://www.kcl.ac.uk/sspp/sga/kii/documents/RAO-Gopal-LectureFINAL.pdf

RENMIN RIBAO. 1951. “Yindu jia’ergeda chengli yinzhong youhao xiehui 印度加尔各答成立印 中友好协会” [India-China Friendship Association established in Calcutta, India]. March 7, 4.

一. 1952a. “Fazhan zhongyin youhao guanxi... 发展中印友好关系...” [Develop Friendly Relations between India and China...]. May 17, 5.

一. 1952b. “Canjia yindu bajisidan guoji gongye zhanlanhui” 参加印度巴基斯坦国际工业展览 会” [Visiting the India-Pakistan International Industrial Exhibition]. June 9, 4.

—. 1955a. “Yindu dianyingzhou jiang zai woguo ershige chengshi juxing 印度电影周将在我国 二十个城市举行” [Indian Film Week to be held in twenty cities across China]. October $4,1$.

一. 1955b. “Zhu ‘yindu gongheguo dianyingzhou’ kaimu 祝“印度共和国电影周”开幕” [Best wishes on the inauguration of the "Indian Film Week”]. October 17, 3. 
—. 1955c. “Yindu gongheguo dianyingzhou shengli jieshu 印度共和国电影周胜利结束”

[Successful conclusion to the "Indian Film Week"]. October 24, 1.

一. 1957. “Zhu yindu zhanlanhui kaimu 祝印度展览会开幕” [Best wishes on the opening of the Indian exhibition]. September 19, 1.

RIEDEL, BRUCE. 2015. JFK's Forgotten Crisis: Tibet, the CIA, and Sino-Indian War. Washington, D.C.: The Brookings Institution Press.

Robinson, JoAn And Sol Adler. 1958. China: An Economic Perspective. London: Fabian International Bureau.

Robinson, JoAn. 1964. Notes from China. New York: Monthly Review Press.

-. 1969. The Cultural Revolution in China. Baltimore, Md.: Penguin Books.

-. 1977. Joan Robinson-Reports from China, 1953-76. London: Anglo-Chinese Educational Institute.

Rostow, Walt Whitman and Richard W. Hatch. 1954. The Prospects for Communist China. Cambridge: Technology Press of Massachusetts Institute of Technology.

Roy ChOWDHURY, DeBASISH. 2008. "China's Bollywood Love Affair.” Asia Times, January 19.

SARKAR, BHASKAR. 2010. "Tracking "Global Media” in the Outposts of Globalization," in World Cinemas, Transnational Perspectives, edited by Natasa Durovicova and Kathleen Newman, 34-58. New York, London: Routledge.

Scharping, ThOmas. 2003. Birth Control in China 1949-2000: Population Policy and Demographic Development. London: Routledge.

Sen, TANSen. 2003. Buddhism, Diplomacy, and Trade: The Realignment of Sino-Indian Relations, 600-1400. Honolulu: University of Hawaii Press.

—. 2010a. "The Intricacies of Premodern Asian Connections." The Journal of Asian Studies Vol. 69, No. 4 (November), 991-999.

—. 2010b. "Changes and Exchanges.” India International Centre Quarterly Vol. 36, No. 3/4, (Winter 2009-Spring 2010), 34-47.

—. 2012. "Introduction: Ji Xianlin and Sino-Indology." China Report 48: 1 \& 2, 1-10.

—. 2013. "Is There a Need for China Studies in India?” Economic and Political Weekly, Vol. XLVIII No. 29 (July 20), 26-29.

-. 2015. "Chinese Sources on South Asia," in Beyond Frames: India, South Asia and the World, edited by Rila Mukherjee, 52-73. Delhi: Primus.

SeTH, VIKRAM. 1983. From Heaven Lake-Travels Through Sinkiang and Tibet. London: Chatto and Windus. All quotes from First Vintage Departures Edition, 1987.

Sharma, NiRmOLA. 2013. "Studying Chinese History in New Delhi." Dissertation Reviews, February 5.

SimON, DAVID, ed. 2006. Fifty Key Thinkers on Development. Abingdon: Routledge.

SingH, SWARAN. 1998. "Three Agreements and Five Principles between India and China," in Across the Himalayan Gap edited by Tan Chung, 505-518. New Delhi: Indira Gandhi National Center for the Arts.

SRINIVASAN, T.N. ed. 1994. Agriculture and Trade in China and India-Policies and Performance since 1950. San Francisco: Institute for Contemporary Studies.

SRINIVASAn, T. N. 2006. "China, India and the World Economy," Economic and Political Weekly Vol. 41, No. 34 (Aug. 26 - Sep. 1), 3716-3727.

State Statistics Bureau. 1959. Ten Great Years (Weida de shinian). Beijing: Statistical Press. 
StRaus, Julia, ED. 2006. “The History of the People's Republic of China, 1949-1976.” The China Quarterly Special Issue. Cambridge: Cambridge University Press.

Tagliacozzo, Eric, Helen F. Siu, And Peter C. Perdue, eds. 2015. Asia Inside Out: Changing Times. Cambridge: Harvard University Press.

TAN, Chung 谭中, ed. 1998. Across the Himalayan Gap-An Indian Quest for Understanding China. New Delhi: Indira Gandhi National Center for the Arts. Online: http://ignca.nic.in/ks_41062.htm.

Thampi, MAdHAVI. 2005a. Indians in China 1800-1949. New Delhi: Manohar Publishers -, ed. 2005b. India and China in the Colonial World. New Delhi: Social Science Press.

Thampi, Madhavi and Nirmola Sharma. 2015. Catalogue of Materials Related to Modern China in the National Archives of India, 1939-1945. New Delhi: Institute of Chinese Studies.

Times of IndiA, THE. 1952. “India-China Friendship, Bombay Conference.” June 21, 3.

—. 1954. "Rousing Reception to Chinese: Artistes Overwhelmed by Floral Tributes.” December $18,5$.

—. 1955a. "China to Exhibit Indian Films: Delegate on Plan for Future.” March 30, 5.

—. 1955b. "Indian Film Festival Opens in Peking." October 18, 8.

—. 1956a. "India and China Warned Against 'Western Trap'.” February 11, 5.

—. 1956b. "Promoting Prosperity of Resurgent Asia.” December 3, 7.

—. 1958. "India’s Ties with China Praised: Promotion of Co-Existence.” February 5, 5.

Tsui, Brian. 2013 “Chinese Views of Tagore and Gandhi: Then and Now.” The China Story, July 29. https://www.thechinastory.org/2013/07/chinese-views-of-tagore-and-gandhithen-and-now/

United NATIONS. 1962. “International Trade Statistics, 1900-1962.” Unpublished UN Draft Paper, May. http://unstats.un.org/unsd/trade/imts/Historical\%20data\%201900-1960.pdf Accessed 26 September 2015

VAn Fleit Hang, KRISTA. 2014. “"The Law has no Conscience”: The Cultural Construction of Justice and the Reception of Awara in China.” Asian Cinema 24: 2, 141-159.

WANG, HANCHUAN 王汉川. 1983. “Dianyingshi shang de shi'er bu “muqin”” 电影史上的十二 部《母亲》 [Twelve “mothers” in the history of film]. Dianying pingjia 09, 30.

WEN, SHIZHEN 文士桢. 1957. “Yindu zhanlanhui (futupian)—zhongyin youyi de xin biaozhi 印 度展览会 (附图片)—中印友谊的新标志 [Indian Exhibition-A new symbol of SinoIndian friendship]. Guangming ribao September 19, 4.

White, Tyrene. 2006. China's Longest Campaign: Birth Planning in the People's Republic, 1949-2005. Ithaca: Cornell University Press.

XUE, KEQIAO 薛克戈羽. 2006. “Jin wushinian woguo zhongyin wenhua guanxishi yanjiu zongshu 近五十年我国中印文化关系史研究综述” [Studies of the History of Sino-Indian Cultural Relations: A Review of the Past Fifty Years]. South Asian Research 《南亚研 究》, No. 2, 76-79.

ZHANG, MINQIU 张敏秋 ED. 2006. Kuayue ximalaya shan zhang'ai-zhongguo xunqiu liaojie yindu《跨越喜马拉雅障碍一中国寻求了解印度》 [Across the Himalayan Gap-A Chinese Quest for Understanding India]. Chongqing: Chongqing Press.

YANG, ANAND A. 2015. "China and India Are One: A Subaltern's Visions of "Hindu China” during the Boxer Expedition of 1900-1901,” in Asia Inside Out: Changing Times, edited by Eric Tagliacozzo, Helen F. Siu, and Peter C. Perdue, 207-225. Cambridge: Harvard University Press. 


\footnotetext{
${ }^{1}$ Nargis was identified with Rita in China. For instance, a short editorial in the journal Movie Review introduced Nargis by simply noting that she played the role of "Lida” 丽达 in Awara (Wang 1983).

${ }^{2}$ The song was popular from the start: the Chinese ambassador especially requested it at a cultural program in Bombay during Zhou Enlai’s December 1956 visit (The Times of India, hereafter TOI, 1956b).

${ }^{3}$ On the remarkably warm reception of Indian films in the Soviet Union, see: Rajagopalan 2008, 2009.

${ }^{4}$ An eleven-member delegation of Indian film-makers, led by the actor Prithviraj Kapoor, was in China during the week. Three films (Do Bigha Zameen, Liang mu di 两亩地; Barsaat, Baofengyu 暴风雨; and Awaara, Liulangzhe 流浪者) and one documentary (Construction and Arts of India, Yindu de yishu yu jianshe 印度的艺术与建设) were screened. Per incomplete data, the movies were screened 3,192 times across 120 theaters (Renmin ribao, hereafter RMRB, 1955a, 1955b, 1955c; TOI 1955b).

${ }^{5}$ A totemic song of 1950s Sino-Indian relations, hindi-chini-bhai-bhai was popular enough by 1954 that it was performed impromptu by four visiting Chinese artists at a reception in Bombay. Another friendship slogan promoted that year, "Swagat pyaare, Chini Bhai hamare [A loving welcome to our Chinese brethren]" seems, however, to have suffered a quiet death (TOI 1954).

${ }^{6}$ Histories of the war began to be written almost as soon as a cessation of hostilities was announced. Mehra (2006) and Dai (2014) provide useful summaries of English and Chinese language scholarship. More recently, Riedel (2015) has written about the 1962 war as viewed from the Kennedy White House and Rao (2014) has provided a diplomat's reflections on the history of Sino-Indian relations.

${ }^{7}$ Writing nearly twenty years later, by which time the legacy of 1962 had already begun to crystallize, Chester Bowles (onetime US Ambassador to India) would echo this formulation (Bowles 1971: 538).

${ }^{8}$ The Center was set up in 1951 under the leadership of Max Millikan to explore ways to combat the spread of communism and was home to several important figures in politics and development, including Walt Rostow, Robert Solow, Paul Samuelson, and Lucian Pye (Simon 2006: 212, Blackmer 2002).

${ }^{9}$ Blackett repeated this sense of China-India competition during an oral history interview several years later (Prof. P.M.S. Blackett, NMML, Oral History Transcripts (\#284), 13-14).

${ }^{10}$ The CCP's success also had an electrifying impact on members of the Indian Left, many of whom actively studied and applied Maoist methods. For a history of the Left in India by one of its most articulate and sympathetic voices see: Bidwai 2015. An earlier sociological analysis of Indian and Chinese attitudes toward each other is Gupta (1972a, 1972b).

${ }^{11}$ My use of "China-India" in this paper is a deliberate attempt to contrast it with the more common Sino-Indian, which has overtly geopolitical and international relations connotations.

${ }^{12}$ The bibliometric data for the charts that follow were drawn from WorldCat and restricted to English language materials dating from 1947 to 2013 . They were collected by writing a program that ran requests using the publicly available WorldCat API. The charts here rely on the following four sets of numbers: (1) books with "China" and "India" or "Sino-India" in the title; (2) articles with "China" and "India" or "Sino-India" in the title; (3) books with "China" or "India" in the title; (4) articles with "China" or "India" in the title.

${ }^{13}$ The pattern of growth, decline, and growth is replicated at the $\mathrm{p}=0.05$ level for books. For articles, the general pattern is less robust: a period of increasing interest, followed by a period of decline (both at $\mathrm{p}=0.05$ ), and then growth $(\mathrm{p}=0.11)$.

${ }^{14}$ Elsewhere, Prasenjit Duara (2010) has noted that China-India studies tend to be caught between a 'civilization vs. realpolitik' binary.

${ }^{15}$ Sen has published extensively on various aspects and periods of China-India history (Sen 2003, 2010a, 2010b, 2012, 2015).

${ }^{16}$ For an accomplished scholarly analysis, see: Duara 1995, in particular Chapter 7 ("Critics of Modernity in India and China”). A more recent work written for a general audience is Mishra (2012).

${ }^{17}$ Space constraints preclude a full discussion of this already rich body of literature. Notable representative examples on the China-side include Kirby 1990 and Strauss 2006; and on the India-side, De 2013 and Gould, Sherman, and Ansari 2013.

${ }^{18}$ Western observers were not entirely unaware of these visits (Li 1962: 13; Rostow and Hatch 1954: 168, 361).

${ }^{19}$ The organization was renamed the Chinese People’s Friendship Association for Cultural Relations with Foreign Countries in 1966 and since 1969 has been known as The Chinese People's Association for Friendship with Foreign Countries. See: http://en.cpaffc.org.cn/introduction/agrintr.html.

${ }^{20}$ The Association was revived in 1992; see: http://en.cpaffc.org.cn/content/details28-22276.html.
} 
${ }^{21}$ The full chronology will be hosted as an online open access contributory database by the Center for Global Asia, NYU-Shanghai.

${ }^{22}$ Author's communication with Narayan Sen, the Indian student; September 42015.

${ }^{23}$ On the statistical exchanges, see: Ghosh 2016.

${ }^{24}$ The Chinese State Statistics Bureau's digest of the first ten years of the PRC devotes a mere two pages to trade and only provides numbers and indices for total exports and imports (State Statistics Bureau 1959: 155-156).

${ }^{25}$ China's estimates include data from North Vietnam, North Korea, and Mongolia Republic and South Asia is defined as India, Pakistan, Burma, and Ceylon (United Nations 1962).

${ }^{26}$ For the text of the agreement, visit: http://www.commonlii.org/in/other/treaties/INTSer/1954/14.html

${ }^{27}$ Christopher Leighton (2010) has shown that the early PRC state had a delicate and far from doctrinaire relationship with its own capitalists.

${ }^{28}$ A memo from the Chinese State Statistics Bureau to the Foreign Ministry acknowledged he had a "worldwide reputation” (quan shijie henyou shengwang 在全世界很有声望) in the area of population research (FMA 10500887-01: 3). A colorful figure in the history of demography, Chandrasekhar was trained at Presidency College, Madras, and Columbia and New York Universities. In 1967, he was appointed Minister of State for Health and Family Planning, from which office he advocated increasingly coercive methods including forced sterilization. In later life, he served as a professor at several American universities including the Universities of Pennsylvania and California (at Los Angeles and Santa Barbara) (Brownlee and Johnson 2004). For an extensive treatment of the evolution of Chandrasekhar's thought and his participation in population research and policy-making, see: Bashford 2014.

${ }^{29}$ For a collection of reviews, see: SCP B32 F88.

${ }^{30}$ In the event, Chandrasekhar's visit was sponsored by the Government of Madras, which approved an INR 4,000 grant, and facilitated by the Indian Government, which sanctioned the visit and made introductions for him in Beijing (SCP B14 F20).

${ }^{31}$ Dated 11 November 1958, this document was marked “Top-Secret” (juemi 绝密). Chandrasekhar had no way of knowing about these instructions, and the gentle, polite stone-walling he encountered infuriated him to no end.

${ }^{32}$ This summary is compiled from Chandrasekhar's unpublished ninety-seven-page tour diary (SCP B19 F43). Where possible, names of places and people have been updated with modern pinyin and Chinese characters.

${ }^{33}$ The Chinese themselves kept a close tab on Chandrasekhar's activities following the trip. In a series of telegrams the Chinese Embassy in New Delhi and the Foreign Ministry in Beijing discussed both the slanderous (wumie 污茂) nature of Chandrasekhar's proclamations as well as the fact that the Chinese had ended up bearing some of his costs (FMA 105-00887-01: 43, 44).

${ }^{34}$ For reference, consider that in 2005 China produced an estimated 2.5 billion condoms out of a global total of 15 billion. Of that number, only 0.5 billion were sold within China (Howe 2005).

${ }^{35}$ Scharping also wrote about the reemergence of traditional contraceptive methods such as the swallowing of tadpoles, something that Chandrasekhar noted as well (SCP B19 F43: 56). 